\title{
Agro-ecological Influence on the Nutrient Status and Physico-Chemical Dynamics of the Ultisols of Rural Ehom, Cross River State, Nigeria
}

\author{
Egbai O. O. ${ }^{1, *}$, Oba D. O. ${ }^{2}$, Ambe B. A. ${ }^{3}$, Abang P. O. ${ }^{4}$, Eneyo V. ${ }^{2}$, Ocheche C. A. ${ }^{5}$ \\ ${ }^{1}$ Department of Environmental Resource Management, University of Calabar, Calabar, Nigeria \\ ${ }^{2}$ Tourism Studies, University of Calabar, Calabar, Nigeria \\ ${ }^{3}$ Department of Environmental Education, University of Calabar, Nigeria \\ ${ }^{4}$ Department of Public Administration, University of Calabar, Nigeria \\ ${ }^{5}$ Department of Geography and Environmental Science, University of Calabar, Calabar, Nigeria
}

Received June 7, 2021; Revised July 17, 2021; Accepted August 22, 2021

\section{Cite This Paper in the following Citation Styles}

(a): [1] Egbai O. O., Oba D. O., Ambe B. A., Abang P. O., Eneyo V., Ocheche C. A. , "Agro-ecological Influence on the Nutrient Status and Physico-Chemical Dynamics of the Ultisols of Rural Ehom, Cross River State, Nigeria," Environment and Ecology Research, Vol. 9, No. 4, pp. 204 - 208, 2021. DOI: 10.13189/eer.2021.090408.

(b): Egbai O. O., Oba D. O., Ambe B. A., Abang P. O., Eneyo V., Ocheche C. A. (2021). Agro-ecological Influence on the Nutrient Status and Physico-Chemical Dynamics of the Ultisols of Rural Ehom, Cross River State, Nigeria. Environment and Ecology Research, 9(4), 204 - 208. DOI: 10.13189/eer.2021.090408.

Copyright $\odot 2021$ by authors, all rights reserved. Authors agree that this article remains permanently open access under the terms of the Creative Commons Attribution License 4.0 International License

\begin{abstract}
A study on the agro-ecological influence on nutrient status and physicochemical dynamics of ultisols was conducted in Ehom in Cross River State, Nigeria. The objective was to ascertain the effect of key traditional farming practices on nutrients and physicochemical properties of soils in the area. Soil samples were manually collected for laboratory determination of these properties. Descriptive statistics was used to determine variation in the textural characteristics of soil while Analysis of variance (ANOVA) was used to test variation in soil chemical characteristics. Results proved that traditional bush burning has beneficial effects of adding potassium (K) into the soil while nitrogen $(\mathrm{N})$ and phosphorus $(\mathrm{P})$ were adequately enhanced through the application of artificial fertilizer on one hand and the incorporation of plant's residues into the soil on the other. Tillage and slashed treatments facilitated soil organic carbon and other plant's nutrients absorption but exerted little or no influence on the textural characteristics of soil. The reason is the value of soil textural classes was not statistically different across treatment blocks. Descriptive statistics also proved that all nutrients/chemical properties of soil were altered considerably as mean $\mathrm{pH}$ values of $5.32 \mathrm{~B} / \mathrm{F}$ and $6.62 \mathrm{~A} / \mathrm{F}$ in burn treatment practice and the soil Organic carbon content also altered considerably from a mean of 2.8 to
\end{abstract}

4.56. Analysis of variance indicates that there was a significant difference in all nutrients/chemical properties of soil at 0.05 probability level indicating that on farm treatment methods altered soil nutrient and chemical properties considerably. The study recommends adoption of sound agricultural practices taking into consideration the prevailing soil and environmental condition.

Keywords Agricultural Practice, Nutrient Dynamics, Physicochemical Properties, Treatment Blocks

\section{Introduction}

Productivity is not an absolute measure but rather a reflection of the ratio between inputs and outputs. An agricultural land doubles in productivity and produces double over the previous years may not be an indication of its fertile status. The increase in productivity may be a function of the prevailing management practice. [9] observed that land treatment method has profound influence on soil nutrient status. Thus, to ensure adequate nutrient in the soil, appropriate treatment measures must be adopted $[15,13]$. The availability of soil nutrient in 
required amount is a prerequisite for the attainment of sufficient food production [7].

The most essential nutrient elements required for increased food production are soil dependent. They are obtained from soil for plant growth and development. The availability of soil nutrients in required amount is an important pre-requisite for the attainment of sufficient food production [7,10]. However, the important soil nutrients constraint have been identified to include excessive removal of vegetation, poor agricultural practices and topography $[1,8]$.

In an agro-ecological environment where soil is nutrient deficient, improvement in soil nutrient is required to be replenished [6,4]. Appropriate land treatment methods must also be adopted [15] [13]. It involves various on farm agricultural practices meant to facilitate crop production processes.

Use of manure to improve soil structure, aggregation, infiltration and microbial activity is advocated by [11] and [12]. However, [3, 5] suggested to treat soil with residue to enhances return rate of Nitrogen and Phosphorus. Burning was earlier known to significantly decrease soil nitrate- nitrogen, available phosphorus and sulphur but increase exchangeable calcium (Ca) and available potassium (K) [2].

Nigeria is known for its rich agricultural potentials. Thus from the northern Sahara to the Southern tropical landscape, high agricultural productivity had never been in doubt except in recent times when a sharp decline in soil nutrient is increasingly noticeable. In Cross River State where Ehom is an integral part of the issue of nutrient depletion is becoming a major source of concern. Thus, a search is always there for alternative land treatment method in order to improve land condition. This paper seeks to assess a variety of land treatment methods with a view to ascertaining their effect on soil nutrient status on one hand and the nexus between physicochemical parameters and the various agricultural treatment methods on the other.

\section{Materials and Methods}

\section{Study Area}

The study was conducted in Ehom, Biase Local Government Area of Cross River State. It is located between longitudes $8^{0} 08$ and $8^{0} 11 \mathrm{E}$ of the Greenwich Meridian and within latitudes $5^{0} 27^{1}$ and $8^{0} 30^{1} \mathrm{~N}$ of the Equator. The landform consists of gentle uniform slope gradient with homogeneous textural characteristics. The landscape can be best described in term of its geospatial characteristics. It is a tropical rainforest soil located within the equatorial climate of $5^{0} \mathrm{~N}$. [17] described soils within this area as tropical rainforest soil having high sunshine, heavy rainfall and considerable moisture content. Such a condition can encourage rapid decay of plant residue as well as favour the adoption of a variety of farming practices with a view to boosting crop production.

\section{Land preparation}

Land preparation was done following the traditional method of clearing. This was so in view of the anthropological activities that has reduced the pristine vegetation to disturb the ecosystem. Four sites were carefully selected to represent the respective treatment blocks viz: tillage, fertilizer, burn and residue/slash blocks. Each of these blocks were subsequently demarcated into five plots (sub-blocks) to represent cassava, maize, melon, cocoyam and mixed crop plots respectively. Each block measured $30 \mathrm{~m} \times 30 \mathrm{~m}$ while the demarcated crops plots measured $5 \mathrm{~m} \times 30 \mathrm{~m}$ each with $1 \mathrm{~m}$ space in-between the plots. The rational for using crops was to reflect the locally grown crops in the area. Soil samples were collected with the aid of soil auger from a depth of $0-3 \mathrm{~cm}$ for Laboratory analysis for the physico-chemical properties Before $(\mathrm{B} / \mathrm{F})$ and $(\mathrm{A} / \mathrm{F})$ treatments were done

\section{Result and Discussion}

The data in Table 1 reveals the means and ranges of soil physical characteristics in the experimental blocks. Result of the particle distribution of means and ranges obtained from the various treatment blocks did not differ significantly, before and after treatments. For example, a range of $68-69 \%$ was obtained $(\mathrm{B} / \mathrm{F})$ and $68-69 \%$ after $(\mathrm{A} / \mathrm{F})$ treatment and a mean of $68.4 \%$ and $69.2 \%$ of sand were obtained before and after treatment in tillage block. Silt range was $16-20 \%(\mathrm{~B} / \mathrm{F})$ and $1512.8 \%(\mathrm{~A} / \mathrm{F})$. While that of clay ranged from $11-16 \% \mathrm{~B} / \mathrm{F}$ and $10-16 \% \mathrm{~A} / \mathrm{F}$ and mean of $13.6 \mathrm{~B} / \mathrm{F}$ and $12.8 \% \mathrm{~A} / \mathrm{F}$ respectively. Similar result replicated itself across the other treatment blocks. The data in Table 2 reveals the coefficient of variation of particle size distribution. The following variation ranges constituted standard for determination of variation. Variation was low (0-15\%) moderate (15-30\%) and high (>30\%). Thus in all the blocks CVs range for sand was $7.6 \%, 14.4-16.0 \%$ for silt and $15.0-16.99 \%$ for clay. The CVs range was within $0-15 \%$ meaning that variation of soil in the treatment blocks was apparently low. Table $1 \& 2$ are useful in explaining the physical characteristics of soils in the area. The above tables reveal that the soils were homogenous thus various treatment method did not exert significant effect on their physical properties. This is probably because it takes a longer time to alter soil considerably to warrant statistical variability [14]. The data in table 3 are the means and ranges of chemical properties taken before $(\mathrm{B} / \mathrm{F})$ and after $(\mathrm{A} / \mathrm{F})$. It reveals that $\mathrm{pH}$ values were altered in burn treatment block with a mean of 6.62 before and 5.6 after treatment and a range of 6.5-6.8 B/F and 5.4-6.0 A/F treatment. This treatment 
proved that plant utilized the burnt plant materials (ash). The total nitrogen (TN) was greatly enhanced in the fertilizer blocks, meaning that the treatment of land with organic fertilizer had contributed immensely by adjusting the mean value from 0.96-1.05 and a range of 0.89-1.02 and 1.0-1.20 indicating positive adjustment. The soil organic carbon (org. C) percent increased indicating positive adjustment. The soil organic carbon (soc) increased considerably in the slash/residue block where plant parts are allowed to decompose. Here it has concluded that the soc increased from a mean of $2.8 \%$ to $4.56 \%$ and range of $2.70-2.96$ and $3.9-7.0 \%$ respectively. Makinde (1996) obtained similar result with different crops.

Table 1. Textural characteristics of soil across treatments

\begin{tabular}{|c|c|c|c|c|c|c|c|}
\hline \multirow{3}{*}{ Treatment block } & \multicolumn{6}{|c|}{ Percentage } & \multirow{3}{*}{ Texture } \\
\hline & \multicolumn{2}{|c|}{ Sand } & \multicolumn{2}{|c|}{ Silt } & \multicolumn{2}{|c|}{ Clay } & \\
\hline & $\mathrm{B} / \mathrm{F}$ & $\mathrm{A} / \mathrm{F}$ & $\mathrm{B} / \mathrm{F}$ & $\mathrm{A} / \mathrm{F}$ & $\mathrm{B} / \mathrm{F}$ & $\mathrm{A} / \mathrm{F}$ & \\
\hline \multicolumn{7}{|c|}{ Residue/Slash } & \\
\hline Mean & 62.8 & 61.9 & 19.0 & 19.2 & 15.4 & 15.4 & \multirow{2}{*}{ SL } \\
\hline Range & $58-65$ & $57-65$ & $18-21$ & $19-20$ & 13.17 & 14.17 & \\
\hline \multicolumn{7}{|c|}{ Burn } & \\
\hline Mean & 66.4 & 67.0 & 15.4 & 14.6 & 18.2 & 17.4 & \multirow{2}{*}{ SL } \\
\hline Range & $64-70$ & $65-70$ & $14-17$ & $13-17$ & $15-19$ & $15-19$ & \\
\hline \multicolumn{7}{|c|}{ Fertilizer } & \\
\hline Mean & 62.8 & & & 21.0 & 15.4 & 15.4 & \multirow{2}{*}{ SL } \\
\hline Range & $58-65$ & $57-65$ & $18-21$ & $19-20$ & 13.17 & 14.17 & \\
\hline \multicolumn{7}{|c|}{ Tillage } & \\
\hline Mean & 68.4 & 69.2 & 180 & 18.0 & 13.6 & 12.8 & \multirow{2}{*}{ SL } \\
\hline Range & $68-69$ & $68-69$ & 16.20 & 15.20 & $11-16$ & $10-16$ & \\
\hline
\end{tabular}

Blocks indicating means and ranges before after treatment

$\mathrm{B} / \mathrm{F}=$ before treatment

$\mathrm{A} / \mathrm{F}=$ after treatment

SL $=$ Sandy Loam

Table 2. Shows coefficient of variation of texture classes (properties)

\begin{tabular}{|c|c|c|c|}
\hline \multirow{2}{*}{ Treatment Block } & \multicolumn{2}{|c|}{ Percentage } \\
\cline { 2 - 4 } & \%sand & \% self & \% clay \\
\hline Tillage & 7.6 & 14.4 & 16.9 \\
\hline Fertilizer & 8.0 & 13.9 & 16.0 \\
\hline Residue & 2.2 & 14.2 & 15.0 \\
\hline Burn & 7.8 & 16.0 & $15.0-16.9$ \\
\hline Range & $7.6-8.0$ & $13.9-16.0$ & \\
\hline
\end{tabular}


Table 3. Soil chemical parameters taken before $(B / F)$ and after $(A / F)$ treatments

\begin{tabular}{|c|c|c|c|c|c|c|c|c|}
\hline \multirow{2}{*}{ Soil Parameters } & \multicolumn{2}{|c|}{ Tillage } & \multicolumn{2}{|c|}{ Fertilizer } & \multicolumn{2}{|c|}{ Slash } & \multicolumn{2}{|c|}{ Burn } \\
\hline & Mean & Range & Mean & Range & Mean & Range & Mean & Range \\
\hline $\mathrm{TN} \%$ & & & & & & & & \\
\hline Before (B/F) & 1.08 & $1.00-1.2$ & 1.02 & $1.0-1-06$ & 1.16 & $1.10-1.20$ & 2.58 & $2.5-2.7$ \\
\hline After (A/F) & 1.02 & $0.0-1.30$ & 0.88 & $0.8-0.9$ & 1.14 & $1.00-1.20$ & 0.5 & $0.3-0.60$ \\
\hline \multicolumn{9}{|l|}{$\mathrm{Mg}(\mathrm{cmo} 1 / \mathrm{kg})$} \\
\hline Before (B/F) & 1.01 & $1.0-1.02$ & $0.96-102$ & $0.9-1.2$ & 0.29 & $0.20-0.40$ & 0.54 & $0.12-1.16$ \\
\hline After (A/F) & 0.92 & $0.8-1.00$ & $0.12-0.14$ & $1.0-1.20$ & 0.29 & $0.11-0.30$ & 0.46 & $0.11-0.98$ \\
\hline \multicolumn{9}{|l|}{ P H } \\
\hline Before (B/F) & 5.02 & $4.9-5.1$ & 5.08 & $4.9-5.2$ & 5.32 & $5.2-5.4$ & 6.62 & $6.5-6.8$ \\
\hline $\operatorname{After}(\mathrm{A} / \mathrm{F}) \mathrm{s}$ & 5.76 & $5.4-6.0$ & 4.06 & $4.8-4.9$ & 5.5 & $5.1-6.0$ & 5.6 & $5.4-6.0$ \\
\hline \multicolumn{9}{|l|}{ Org. C\% } \\
\hline Before (B/F) & 1.19 & $1.18-1.20$ & 1.90 & $1.89-90$ & 2.8 & $2.70-2.96$ & 2.58 & $2.5-2.7$ \\
\hline After (A/F) & 2.54 & $2.00-3.00$ & 2.30 & $1.69-4.70$ & 4.56 & 3.9-7.0 & 1.174 & $1.6-1.9$ \\
\hline \multicolumn{9}{|l|}{ A.V.P $(\%)$} \\
\hline Before(B/F) & 3.10 & $3.0-3.2$ & 2.42 & $2.19-2.60$ & 3.72 & $3.69-3.8$ & 3.64 & $3.6-3.8$ \\
\hline After (A/F) & 2.82 & $2.70-3.00$ & 2.48 & $2.2-2.9$ & 3.57 & $3.31-3.70$ & 3.34 & $3.1-3.5$ \\
\hline \multicolumn{9}{|l|}{$\mathrm{Ca}(\mathrm{cmo} 1 / \mathrm{kg})$} \\
\hline Before (B/F) & 1.70 & $1.6-1.80$ & 3.29 & $3.25-3.40$ & 303 & $3.0-3.1$ & 3.14 & $3.0-3.8$ \\
\hline After (A/F) & 1.70 & $1.50-1.80$ & 3.22 & $3.0-3.40$ & 3.01 & $3.0-3.01$ & 2.7 & $2.6-2.8$ \\
\hline \multicolumn{9}{|l|}{$\mathrm{Na} \mathrm{cmo} 1 / \mathrm{kg}$} \\
\hline Before (B/F) & 0.06 & $0.6-07$ & 0.08 & $0.07-0.09$ & 0.09 & $1.1-1.20$ & & $0.05-0.15$ \\
\hline After (A/F) & 0.06 & $0.04-0.08$ & 0.08 & $0.06-0.12$ & 0.10 & $1.0-1.20$ & & $0.09-0.14$ \\
\hline $\mathrm{K} \mathrm{cmo1/kg}$ & & & & & & & & \\
\hline Before (B/F) & 0.09 & $0.08-01.0$ & 0.13 & $0.4-0.5$ & 2.70 & $0.11-1.16$ & 2.14 & $2.13-2.17$ \\
\hline After (A/F) & 0.08 & $0.06-0.10$ & 1.03 & $0.45-0.55$ & 0.11 & $0.09-0.14$ & 1.50 & $1.12-2.10$ \\
\hline
\end{tabular}

Table 4. Soil chemical due to treatment methods

\begin{tabular}{|c|c|c|c|c|c|}
\hline Soil parameters & Sign of squares & DF & Means square & F.cal & Sign \\
\hline AN.P & 9.19621 & 3 & 3.0654 & 132.04 & $<001$ \\
Ca & 14.3558 & 3 & 4.7852 & 365.27 & $<001$ \\
K & 6.6534 & 3 & 0.5511 & 1331.49 & $<001$ \\
Mg & 2.0027 & 3 & 0.6675 & 56.78 & $<001$ \\
Na & 0.0181 & 3 & 0.0060 & 19.69 & $<001$ \\
Soil Org. C & 23.0464 & 3 & 7.6821 & 30.36 & $<001$ \\
TN & 4.0437 & 3 & 1.3479 & 20.71 & $<001$ \\
PH & 6.6960 & 3 & 2.2320 & 43.34 & $<001$ \\
\hline
\end{tabular}

The exchangeable bases $(\mathrm{Ca}, \mathrm{Mg}, \mathrm{Na}$ and $\mathrm{K}$ ) were affected by the various treatment methods thus, there was reduction in the mean and ranges of $\mathrm{Ca}, \mathrm{Mg}, \mathrm{Na}$ across blocks while range value of potassium (K) altered positively from $0.12-0.14$ to $1.00-1.06$ and mean value from 0.13 to 1.03 which indicated an increase in value. Similar result was also obtained in burnt block. The data in Table 4 shows variation in soil chemical properties due to treatment methods. It was evident that there was significant different at 0.05 level of probability implying that land treatment method altered soil nutrient status significantly in the study area.

\section{Conclusions}

Soil nutrient management is essential for sustainable agricultural production. Appropriate farming practice is capable of modifying and influencing on soil nutrient status. The efficacy of these nutrients reflects the soil's ability to stimulate growth potentials in crops and enhancement of textural and structural stability of soil through residue enrichment process. In an agro ecological environment where soil inhibiting factors are prevalent, adequate knowledge of nutrients and physicochemical dynamics can doubtless constitute veritable platforms for optimal utilization of agricultural landscape for increased food production. The significance of the study can be viewed from the perspectives of the contributions of various farming practices. For example, traditional bush burning has attendant beneficial effects of adding some amount of potassium into the soil while Nitrogen $(\mathrm{N})$ and phosphorus (P) were adequately enhanced through the 
application of fertilizer on one hand and the incorporation of plant's residues into the soil. Tillage and slashed treatments facilitated organic carbon and other plant's nutrients absorption but exerted little or no influence on the textural characteristics of soil.

\section{REFERENCES}

[1] Anyanwa, A., Anyanwa, B. O. \&Anyanwa V. A "Crop production" in A text book of Agricultural science for schools and colleges, $6^{\text {th }}$ ed, AFP, 2001, pp. 242-248

[2] Azeez, J. O., Adetunji, M. T. \&Adebusuyi, B. "Effect of residue burning and fertilizer application on soil nutrient dynamic and dry gain yield of maize (Zea mays L.) in an Alfilsol." Nigeria Journal of soil science vol. 17, no. 2 pp. 71-79, 2007.

[3] Beri, V., Siaihu, B. S., Mahl, G.S. \&Bhat, A. K "Nitrogen and phosphorus transformations as affected by crop residue management practices and their influences on crop yield". Soil use and management vol. 11, no. 1 pp. 51-54, 1995.

[4] Castillo, A. E., Benito, S.S. \&Fernandes, J.A. "Using organic manures as liming materials". Agrochemical, vol. 27 no. 7, pp. 14-20, 2003.

[5] Clap, C.E., Allmeras, R. R., L; layese, M. F Linden, D. R. \&Dowody, R. H. "Soil organic carbon and carbon abundance as related to tillage crop residue and nitrogen fertilization under continuous crop management in Minnesota" Soil and tillage Research vol. 55, pp.127-142, 2000.

[6] Corwin, D., Kaffka, S. R., Hopmans, J. W. Mori, Y., Groeingen, J.W., Vnkessel, C., Vanlesch, S. M \& Oster, J.D. "Assessment and field scale mapping of soil quality properties of saline sedic soil" Geoderma, vol. 114 no. (3/4), pp. 231-259, 2003.

[7] Egbai, O. O, Nkik, E., Uquentan, U. I. "Influence of soil textural properties and land use cover type on soil erosion in
Betem, South-South Nigeria". Journal of Sustainable Development. vol. 4 no. 40, pp. 222-229, 2011.

[8] Egbai O.O. "Effect of crop cover on soil susceptibility to erosion in southeastern Nigeria". Journal of physical science and environmental studies vol. 2 no. 4 pp. 50-57. 2016

[9] Eze, E. B \& Egbai, O.O. "The effect of traditional land management methods on sustainable crop yield in Betem, Biase Local Government Area of Cross River State Nigeria”. CAB Inter. Publ. 2018, pp. 75-80

[10] Fagbola, O \& Ogungbe, P. W. "Growth and yields response of some maize cultivars to organic fertilizer application in stimulated degraded soil under green house condition." Nigeria Journal of soil science, vol. 19, pp. 187-198. 2007.

[11] Gulley J. E. \&Rigge M. "soil loss as affected by the application of manicure". Transaction of the ASAE, vol. 43, pp1583-1588. 2000.

[12] Haynes, R.J \&Naude, R. "Influence of time, fertilizer and manure application on soil organic matter content and soil physical conditions: A review". Nutrient cycling in Agroecosystem, vol. 51, pp. 123-137. 1998

[13] Kiani, M. J., Abbas, K. M \& Rahim, N. "use of organic manicure with in fertilizer increases wheat yield at RawakalotAzed Jammuand Hash min" Archives of Agronomy and soil science, vol. 51, pp. 199-209. 2005.

[14] Singe and Munns (1999). "Mineral nutrients in soils and plant" in Soils anintroduction. 4thed. New Jersey Practice Hall. 1992. Pp. 228-234

[15] Soummere., M. Tack, F. M. G. \&Valoo, M. G (2003). Effects of municipal solid waste compost and mineral fertilizer on plant in two tropical agricultural soils of Mali Bloresource Technology, 86, 15-20.

[16] Spaargaren, O. C. (1994). World references base for soil resources. Rome, food and Agricultural organization.

[17] Waugh, D. "Farming and food supply" in Geography: An integrated approach $2^{\text {nd }}$ ed. London Thomas Nelson and Son. 1995, Pp. 220-225. 